\title{
STRATEGIES AND TECHNOLOGIES OF ADAPTIVE MANAGEMENT OF HIGHER EDUCATION INSTITUTIONS IN A RAPIDLY CHANGING EXTERNAL ENVIRONMENT
}

\author{
Mykola Kovalenko', Oksana Lomonosova ${ }^{2}$, Alla Rusnak ${ }^{3}$
}

\begin{abstract}
The purpose of the research is to analyse management models and development strategies of higher education institutions (HEIs), to describe ways, methods and technologies of their adaptation to the rapidly changing conditions of the external environment of operation. The method of complex research allows to analyse existing strategies of development of Ukrainian universities and to elaborate recommendations on organizational and economic support of adaptation of the HEls to changes in external environment. The methodological basis of the research is based on a systematic approach to the substantiation of the essence and types of development strategies of higher education institutions, the processes of their adaptation to changes in the external environment of their functioning. The concept of adaptive management of HEls is proposed to be considered a synergistic combination of regularities, organizational principles in the process of applying effective methods, algorithms, management model for the implementation of the most important directions of solving multifaceted problems of adaptation of HEls to changes in the environment in order to ensure its effective functioning, competitiveness in the market of educational services. Scientific results. The results of the research show that the continuous process of adaptation of HEls to changes in the external environment requires the formation (clarification, improvement) of organizational and economic mechanism of adaptation, implementation in the overall management system of the institution, ideology of adaptive management, bringing the regulatory framework in line with the objectives of modernization of the educational process. Adaptive management should comprehensively cover all subsystems of the HEl's management: operational, educational, scientific, technical, financial and investment, innovation, marketing, personnel, which do not function in isolation. Practical significance. The system of adaptation process support in the HEls should provide for development of action programme for institution adaptation to external environment challenges, which includes adequate organizational and economic adaptation measures, providing the whole complex of actions - from mobilization of all available competitive factors, financial, labour and other resources to staff retraining, etc., taking into account principles of adaptive process. Value/originality. The scientific and methodological bases of the organization of support of the adaptation process in a higher education institution formulated in the article take into account the specifics of educational activity, the need to forecast it for the medium and long term, provide for planning adaptation transformations of HEls on a longterm basis. The results of implementing the adaptive management strategy can be determined by the criterion of improving the quality of education, the individual educational outcome of the graduate as the ratio between the actual level of competencies acquired by him or her and the normative competencies, established by the regulatory educational documents for this educational specialty, specialization.
\end{abstract}

Key words: higher education institution, development strategy, adaptation, external environment, management model, adaptive management technology.

JEL Classification: I21, I23, H12

\footnotetext{
Corresponding author:

${ }^{1}$ Kherson Branch of the Admiral Makarov National University of Shipbuilding, Ukraine.

E-mail: kovalenko45@ukr.net

ORCID: https://orcid.org/0000-0003-0235-7823

${ }^{2}$ Kherson Branch of the Admiral Makarov National University of Shipbuilding, Ukraine.

E-mail: alvirginis@gmail.com

ORCID: https://orcid.org/0000-0003-4760-8542

ResearcherID: V-4858-2017

${ }^{3}$ Kherson Branch of the Admiral Makarov National University of Shipbuilding, Ukraine.

E-mail: rusnak av@meta.ua

ORCID: https://orcid.org/0000-0002-3198-2866

ResearcherID: AAC-7821-2019
} 


\section{Introduction}

The system of higher education in Ukraine is undergoing radical reform. The institutional operational conditions for educational institutions are changing. In the external environment of operation, conditions are formed at a high rate, which determine the features of current and future activities. The most important of them include: informatization of society, digitalization in all spheres of life; formation of market relations, including the transition of higher education institutions (HEIs) to a market logic of operation; reforming the economic complex of the country; formation of the knowledge economy, increasing the role of the human factor in modern production; globalization of economic relations and internationalization of the education sector.

Discretion, instability of operating conditions require from HEIs constant attention to current changes in the external environment. The development of technical progress, socio-economic relations in society and the associated growth of requirements for the competence of graduates, dynamic changes in the labour market, emergence of new professions require from educational institutions new approaches to planning their activities, forecasting the future needs of the economic complex of the country, region in specialists with high compliance with current and future demands of the population and economic entities in relevant knowledge demanded in the labour market.

These environmental determinants require that the HEIs make balanced decisions on the institution's development strategy and adapt to a new, rapidly changing operating conditions.

Nowadays, it has become obvious to develop a survival strategy for the HEIs in today's economic and social environment. However, as the analysis of practice shows, this raises a number of methodological and practical issues, the solution of which will contribute to improving the efficiency of HEIs in the educational service market. The methods of choosing the model of activity of an educational institution in the conditions of the dynamic market of educational services and adaptation to its challenges become especially relevant.

The novelty of the study consists in the improvement of the scheme of organizational and economic support for the adaptation of HEIs to changes in the external environment; defining the role and place of adaptive management technologies in the system of strategic management of HEIs.

The purpose of this article is to analyse management models and development strategies for higher education institutions and to formulate ways, methods and technologies of adapting them to the rapidly changing external environment in which they function.
The research is based on a systematic approach to defining the essence and types of development strategies of higher education institutions and the processes of their adaptation to changes in the external environment of their functioning. The main tasks are: justification of the essence and types of development strategies for higher education institutions; research on the essence and processes of adaptation of higher education institutions to changes in the external environment; generalization of the essence and characteristics of adaptive management of higher education institutions; analysis of existing development strategies for universities in Ukraine.

\section{Actual scientific researches and related issues}

The issue of managing the HEIs in modern conditions of their functioning is raised by foreign researchers, in particular Z.N. Avilova (the role and place of HEIs in the process of recovery of intellectual capital of the region), F.J. Altbach (formation of world-class research universities), T.I. Afasizhev and V.A. Teshev (adaptation of HEIs in conditions of budget financing crisis), M.A. Bolgova (socio-economic analysis of strategies of HEIs in the Russian Federation), Z.N. Gelmanova (issues of improvement of the management system of a modern educational institution), M. Gibbons (new knowledge production), G. Itskowitz (ways to entrepreneurial university), B. Clark (creating entrepreneurial universities: organizational ways of transformation and problems of higher education), A.K. Kliuev (institutional strategies of universities and methodological guidelines for educational institution strategy development), T.A. Kliachko (economic and social aspect of the adaptation strategies of higher education institutions), S. Marginson (public and private in higher education: synthesis of economic and political approaches), P. Mendoza (academic capitalism and socialization of candidates for obtaining a degree of Doctor of Sciences), P. Naletova (modern socio-cultural models of universities), F. Newman (higher education policy in a competitive world), M. Olsen (neoliberal competition in higher education today: research, accountability and impact), R. Rodes (university reform in a global time), A.V. Siganova (general issues of strategic management in higher education institution), P. Scott (academic values and organization of academic activities in the era of globalization), S. Slaughter and L. Leslie (politics of academic capitalism and entrepreneurial university), C. Walkman (entrepreneurial learning in higher education), I.D. Frumin (problems forcing Russian universities to change), P. Schulte (strategy of institutional development of entrepreneurial university), J. Youtie and P. Shapira (creating an innovation centre on the example of transforming the role of universities in regional technological and economic development). 
Domestic scientists also pay considerable attention to these issues in their publications: L.I. Antoshkina (the scientific and methodological foundations of state regulation of higher education), V.I. Astakhova (role of state and non-state HEIs in the education system), T.M. Bogolib (principles of HEI's management), A.Yu. Yushchenko (global trends and problems of educational development and their consequences for Ukraine), L.V. Kryvenko and L.I. Dmytrychenko (strategy of development of the national system of education and science in the context of the European choice), A.O. Maliukina (analysis of the market of educational services in Ukraine), S.A. Matiukh (methods of integrated assessment of the effectiveness of HEIs), V.N. Parsiak (management of university development in modern conditions), L.V. Pshenichna (state assistance in adapting the higher education system in Ukraine to the requirements of the Bologna process), Yu.O. Rosina (strategy for reforming higher education in Ukraine), I.V. Stankevych (innovative strategies and tactics for ensuring the quality of higher education in Ukraine), T.V. Siomkina (adaptation of domestic HEIs to functioning in the conditions of modern institutional environment), O.V. Chernysh (strategic management of educational activities in HEIs), P.A. Yakubek, I.V. Shaposhnikov and K.S. Shaposhnikov (directions of adaptation of world experience of development of higher education in Ukraine in the period of formation of information economy), M.Ya. Yastrubskyi (activity of HEIs in Ukraine: harmonious development, state regulation, investment and innovation support), T.A. Yashchuk (market of educational services: essence and development tendencies) etc.

However, the publications of these and other authors do not sufficiently reveal the issues of adapting the educational institution to modern and predictable changes in the external environment, choosing the model and methods, technologies of management of the institution in order to ensure its competitiveness, successful operation in the market of educational services in a rapidly changing environment.

\section{Essence and types of development strategies of HEIs}

Sustainable development of Ukraine, its integration into the European and world educational space causes the need for radical rethinking of the system of organization and content of education, which provides for, first of all, the creation of a democratic strategic model of management in education, which should comply with European standards of education and contribute to the intellectual and spiritual development of personality, training a competent, competitive specialist, able to solve the problems of our time (Zablotskyi, Palant, Diegtiar, Glibko, Bielska, Rusnak, 2019).

The modern market logic of domestic HEIs provides for the necessity of strategic approaches to institution management. Their use has become an adequate, effective means to organize the achievement of goals and implementation of tasks under conditions of rapid and poorly predictable changes in the educational service market and the environment.

Researchers of the problems of management of higher education institutions have practically come to the predominant conclusion that the strategy of higher education is a comprehensive, long-term plan of systemic actions and their actual implementation based on a comprehensive study of all regularities, external and internal circumstances, set goals and tasks, which ensure efficiency of an educational institution activity (Titova, 2008). The strategic approach provides for an opportunity for integrated use of all various tools of adaptive management and obtaining a synergistic effect of their implementation.

N.L. Titova (Titova, 2008) believes that under the conditions of superfast and poorly predictable changes in the external environment, as well as a sharp reduction in the usual sources of funding, the strategies of HEIs are adaptive in nature. The same point of view is held by T.L. Kliachko (Kliachko, 2002). These strategies vary widely, from conservative to expansionist. The choice of strategy is determined not only by the results of the analysis of the regional educational market, which is changing, but also by the managerial potential of higher education institutions, which is often insufficient for making a decision on restructuring an educational institution, necessary for long-term success (Titova, 2008). At the same time, the important factor of choice - resource factor - practically does not play a significant role and the reason is obvious: general underfunding in the 1990s - the 2000s (Kuzminov, Semenov, Frumin, 2013).

In foreign and domestic practice of modelling strategies of functioning and development of HEIs, taking into account the current and predictable situation in the world market, in the economic complex of the country, region, depending on the features of corporate culture and personalities of the higher managers of the institution, different ways of implementation of the chosen strategy are used. For example, by results of the analysis of a set of HEIs, researchers (Bolgova, Podlegaev, 2015) referred to this or that of the strategies allocated as a result of modelling, have made the following conclusions:

1. "Maximum quality" is a strategy of intensive development, which is basically aimed at improving the core activities of HEIs with a high level of quality of education and average financial condition. 
2. "Financial benefits" is also a strategy of intensive development of the HEIs. This strategy is based on maximizing the current financial results of the core activity of the institution. In HEIs, adhering to this strategy, the level of financial income is high, the scale of activities is expanding.

3. "Diversification" is a strategy, according to which, on the one hand, non-core activities of HEIs start to increase for various reasons. On the other hand, the reason for this direction of development was the small capacity of that market of educational services, which they were initially focused on.

4. "Globalization" is a strategy for the quantitative growth of the core activities of HEIs. This can include universities from small cities, as well as peripheral HEIs of architectural and construction profiles.

5. "Conservative" is a strategy with a stable policy, which is not characterized by significant changes in any parameters of activity. This strategy is followed by classical universities, as well as technical, pedagogical, architectural and construction HEIs, which are located in large and medium-sized industrial cities.

6. "Stagnation" is a strategy, which can be characterized by the deterioration of most of the resultant indicators of HEIs. This set includes, first of all, regional HEIs and classical universities located far from the capital.

M.A. Bolgova and A.V. Podlegaev note that the absorption of peripheral higher and secondary vocational education institutions (conversion of the latter into their branches) by some HEIs resembles the strategy known in business as "Umbrella", in which the mergered business entities begin to develop using the image of large and well-known companies. The creation of branches and representative offices in different regions by such HEIs is close to the use of "Umbrella" business strategy (Bolgova, Podlegaev, 2015).

\section{Essence and processes of adaptation of higher education institutions to changes in the external environment}

Studyportals' experts highlight such institutional archetypes of higher education that can ensure successful educational activities in the future (Ministry of Education and Science of Ukraine, 2020):

- a niche research institute - a generator of knowledge from curricula that focuses on being "the best in the world" in specific disciplines, ideally tied to an industry centre;

- elite, general education university - a generator of interdisciplinary knowledge. In the future, there will be a narrowing of opportunities for such institutions in the world, increasingly they have to specialize and become niche;

- "higher education club" - an implementer of training programmes that focuses on gaining experience by students, the main learning technologies: mentoring and facilitation;

- a scalable digital university - an implementer of training programmes that focuses on flexibility, learning platforms, automated support, improved access, a prerequisite for success is the digitalization of all educational processes and large scales of activity, internationalization;

- a vocational training institute - an implementer of training programmes that focuses on the value of career development, which is achieved through strong ties to industry.

The changes taking place in higher education marked the so-called "second university revolution", as a result of which the main task of the university, along with educational and scientific activities, became to provide a contribution to the economic development of a new type of society - the knowledge society (Douglas, 2009). The reduction of state funding pushed universities to commercialize their activities, which was reflected in the growth of the contingent of foreign students, the attempt to obtain additional funds from grants, income from patent activity, sponsorship, the creation of specially allocated funds (endowments), etc. In the context of internationalization of higher education, international education has become a promising direction. International education began to be considered as a commodity, and the possession of it as a benefit rather than a social obligation. Today even issues of accessibility and obtaining vocational education are increasingly considered in terms of ensuring national or regional competitiveness (Douglas, 2009).

John Goddard argues that "a modern university should understand the importance of building ties with local business, supporting local clusters, creating an international network of connections, and all these actions should be the centre of the region's development strategy" (Foray, Goddard, Beldarrain, Landabasso, McCann, Morgan, Nauwelaers, Ortega-Argiles, 2012). This topic is also developed in the works of such famous scientists as E. Carayannis (Carayannis, Barh, Campbell, 2012). T. Saunders (Saunders, 2007), M. Makkula (Makkula, 2013). Foreign experience points to specific and effective forms of cooperation between industry, public administration and local government in ensuring the region development (the model of innovation system in the form of a triple helix).

The above defines the directions and strategies for further development, internal restructuring, and the content of reforms in the future educational activities of HEIs. These are processes of adaptation of an educational institution to changes in the external environment.

Analysis of existing definitions of adaptation of organizations to changes in external environment, formulation of the author's interpretation of the essence of adaptation of higher education institutions 
on this basis and determining the main factors of the external environment affecting the HEIs, is given in (Lomonosova, 2020). In particular, it is shown that in economics, when interpreted broadly, adaptation is understood as "the adjustment of the economic system to real conditions" (Azrilian, 1999). An example of a more complete definition could be that given in the "Economic Encyclopaedia" (Mochernyi, 2017). According to it, adaptation is "the adjustment of the economic system and its individual entities, employees to the conditions of the changing external environment, production, labour, exchange, and the vital needs of the population ... new relations".

Taking into account the specifics of higher education institutions, as a result of their own research, the authors determine that the adaptation of a higher education institution is its response, which is a purposeful process of forced adaptation to the current and projected changes in the external environment in order to ensure effective fulfilment of the demands of consumers of educational services and its own competitiveness in the market.

The adaptation of the HEIs to changes in the external environment is a complex, multi-aspectual process, which requires not one-time, short-term measures, but balanced strategic decisions capable of overcoming challenges and becoming more effective, competitive. Therefore, the expediency of developing a strategy for HEIs' survival in the modern environment in our time is obvious.

Educational organizations depending on the state and directions of the society development, macro, meso economics, and entrepreneurial organizations in the region, in accordance with the real and expected requests of consumers (customers) of educational services, in each period of time elect the strategy of activity that is most suitable in accordance with the situation in which they are. That is, the HEI chooses the direction of its activities, depending on the environment in which it acts, and from the presence of resources that it possesses.

\section{Adaptive management of a higher education institution}

It is expedient to consider the essence of adaptive management of a higher education institution as a process of creating conditions for the implementation of social requirements for quality, up-to-date knowledge received by graduates, compliance of their competencies with modern and future economy in the personnel training process; appropriate transformations in all structural units of HEI taking into account their functions, basic state, direct or indirect relation to implementation of adaptive goals and tasks of organization; as a process of adaptation of the HEI to socio-economic and institutional changes in society, to the growing needs of people in knowledge. The concept of adaptive management of the HEI is proposed to be considered as a synergistic combination of regularities, organizational principles in the process of applying effective methods, algorithms, models of management of implementation of the most important directions of solving multiaspectual tasks of adaptation of HEI to changes the external environment to ensure the effectiveness of its functioning, competitiveness in the market of educational services.

The continuous process of adaptation of HEIs to changes in the external environment requires the formation (clarification, improvement) of an organizational and economic adaptation mechanism, the implementation of adaptation management ideology into the general management system of the institution, bringing the regulatory framework in line with the objectives of modernization of the educational process. Adaptive management should comprehensively cover all of the management subsystems of HEI: operational, educational, scientific, technical, financial and investment, innovation, marketing, human resources, which do not function in isolation. Considering the continuity and extremely high speed of changes in economy and society, the principles and technologies of adaptive management should become a permanent tool to ensure that the educational institution meets the requirements of the present and future economy and its competitiveness on the educational service market. Adaptation of HEI to changes in the external environment should be a key objective (although not the main objective) of each of the organization's management functions. Each part of the overall management structure has a specific role in the implementation of the institution's adaptation programme. The defining characteristic of a modern adaptive organization can be the institution's marketing service. The organizational and economic mechanism should be regarded as a set of interrelated elements that ensure the operational restructuring of all the subsystems of the HEI for the management of activities to achieve maximum efficiency under changes in the external environment that arise or are projected to arise. It is a set of principles, tools and techniques for making and implementing adaptive management decisions. The multivariance, diverseness, complexity of the adaptation process requires the development of an adaptation strategy for HEI, which in turn requires the development of a concept to build an appropriate organizational and economic mechanism. The concept of an adaptation process should be based on a clearly defined objective and be based on substantiated and practically proven principles.

The management of the adaptation process of HEIs needs a system for developing organizational and economic support for adaptation. The stages of its 
formation are as follows (Sokolova, 2006): analysis of the existing state of adaptation management, choice of system objectives by management levels, identification of functional subsystems, organization of personnel, information, logistical, regulatory and financial support. The synthesis of the adaptation system must take place - choice of the type, structure, constituent elements and defining the architectonics of the system (Figure 1).

It is also necessary to determine how the adaptation system should function. The process of adaptation is aimed at solving three main tasks: ensuring the viability and further sustainable development of the organization in the long-term on the basis of establishing a dynamic balance with the external environment; increasing the level of competitiveness of the HEIs on the market of educational services. In order to achieve the goal set, it is necessary to organize the process of solving a set of tasks and ensure their implementation.

The system of support for the adaptation process in HEIs should provide for the development of an action programme (Figure 2) on the adaptation of the institution to the challenges of the external environment, which includes adequate organizational and economic measures for adaptation, providing for

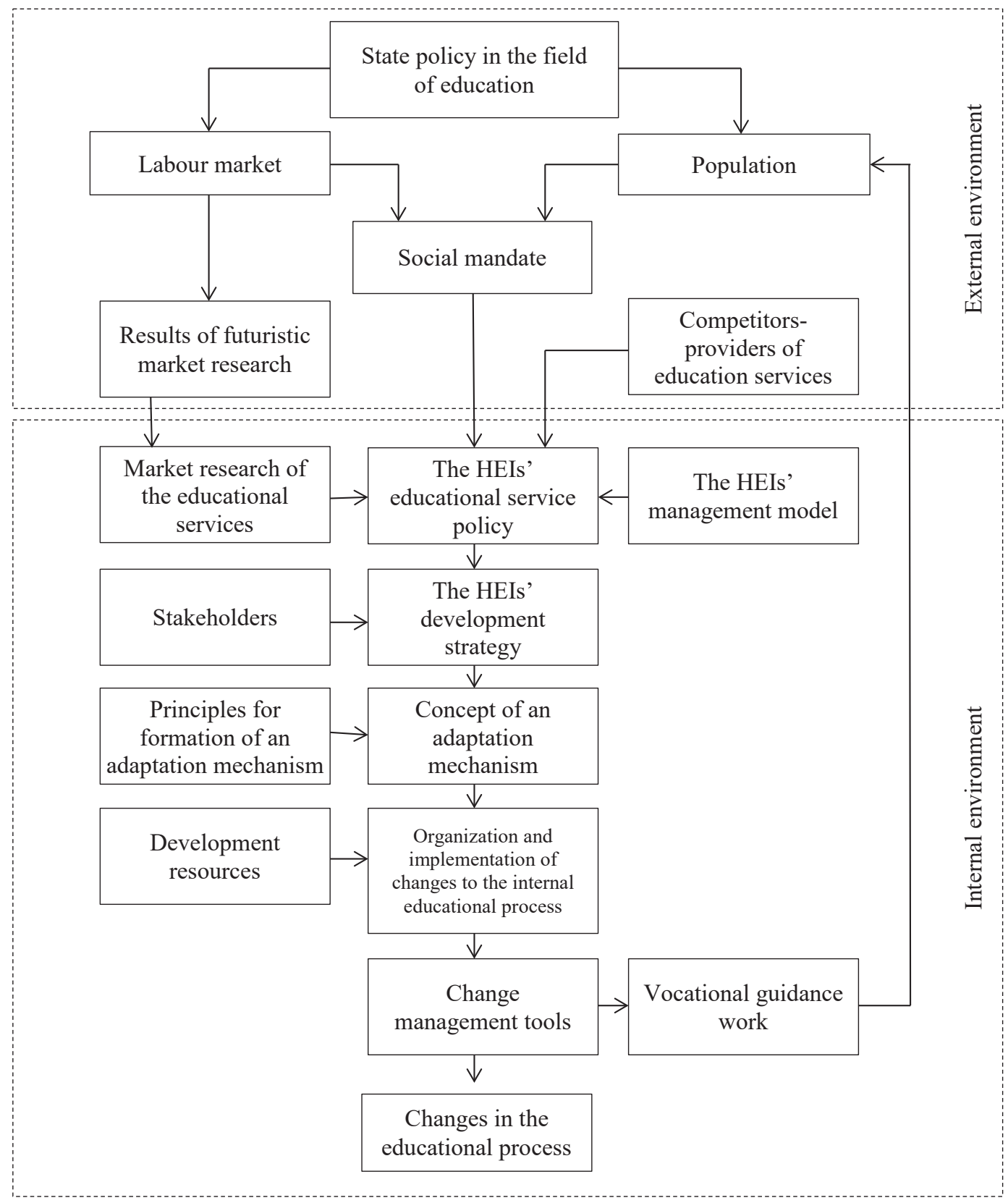

Figure 1. Scheme of the organizational and economic support for the adaptation of HEIs to changes in the external environment 
the whole range of actions - from mobilization of all available competitive factors, financial, labour and other resources to re-training of personnel, etc., formulated taking into account such principles of the adaptive process as follows:

- consideration of the practical experience of targeted modernization activities of other, primarily domestic, HEIs in dealing with similar problems;

- analysis of the current situation of HEIs and the education market and the prospects for their development;

- reliance on the corporate culture of their team;

- comprehensive approach to solving economic and social problems;

- project-based approach to forming and implementing activities to ensure an adaptation programme.

The main content of organizational and economic measures to ensure the adaptation of HEIs to changes in the external environment is the creation of conditions for improving the quality of graduate education, proficiency enhancement of teachers, their training in methods and ways of teaching, adequate to the new requirements of society, the features of modern student audience, the personal qualities of students. An important element of this mechanism should be a subsystem of motivation and encouragement of active participation of personnel in the process of HEI's adaptation to changes in the external environment.

Under present-day dynamic operating conditions, HEI is obliged to become an adaptive organization that is self-learning, responding to real and expected changes in the external environment by changing its systems, structures and procedures, on the one hand, and by changing the skills, knowledge, skills and attitudes of its personnel, on the other hand.

Personnel training, self-training and motivation is one of the most important areas of management improvement in times of internal changes within an organization and its adaptation to external changes.

Scientific and methodological basis for substantiation of managerial decisions on formation of adaptive transformation processes scenario, providing for the choice of the desired scenario based on the principles of unity of education with science and production, compliance of graduate competencies with the requirements of the transformation process taking place in Ukrainian HEIs, formation of students' ability to navigate the virtually limitless information field of speciality, specialization, for learning throughout his or her professional life.

Depending on the role, scale and importance of adaptive elements, as well as the readiness of HEIs to implement an adaptive response, the following

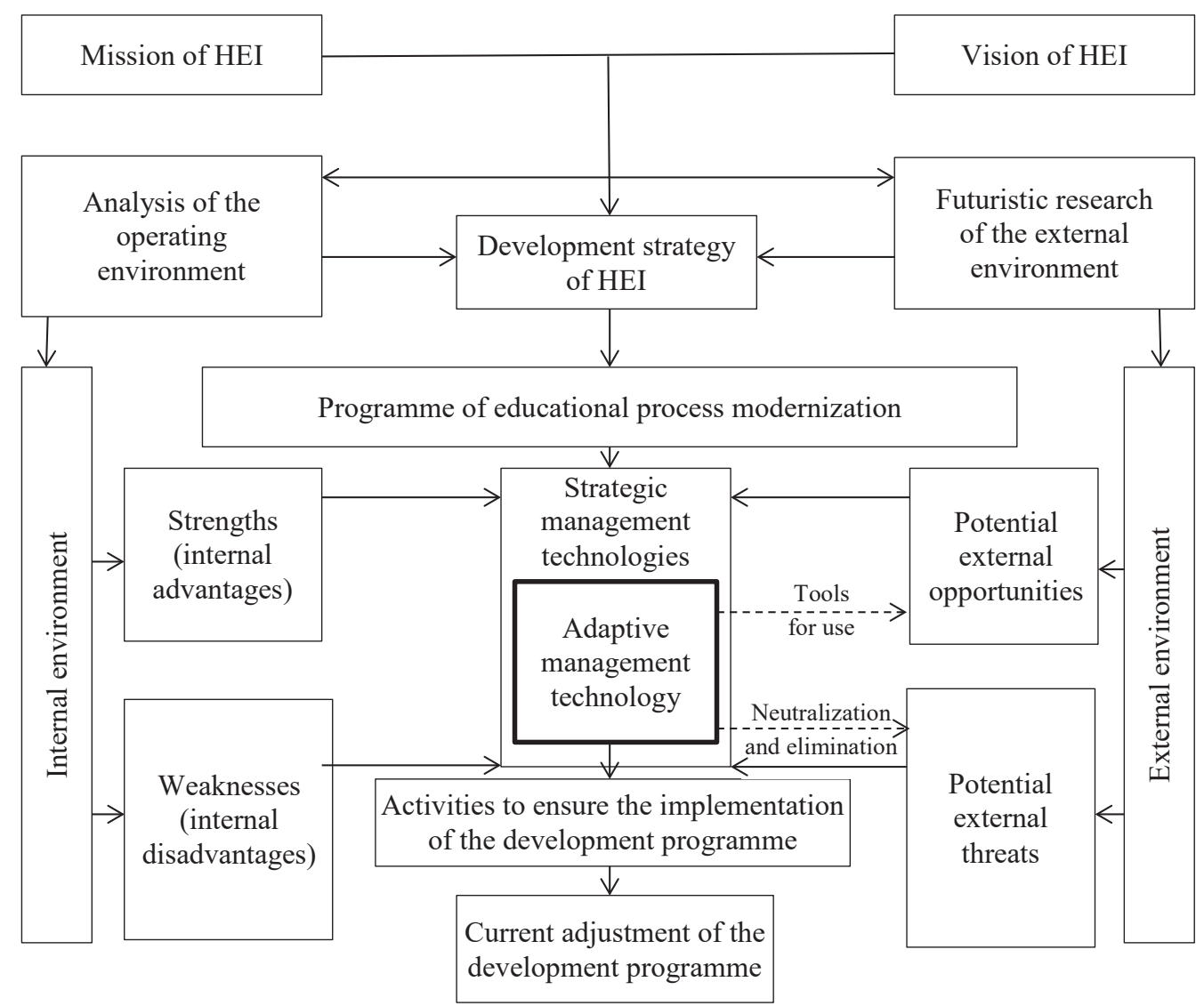

Figure 2. Role and place of adaptive management technologies in the HEIs' strategic management system 
adaptive management tools are distinguished (Zhdamirov, 2010): modernization, restructuring, re-engineering. In our opinion, the specifics of an educational institution's activity and its need to focus on medium- and long-term prospects of educational services market development stipulate mandatory use of such tools as foresight (Volkov, Kuzminov, Remorenko, Rudnik, Frumin, Yakobson, 2008), market research (Verkhovna Rada of Ukraine, 2017), market monitoring, etc.

\section{Analysis of existing HEIs' development strategies in Ukraine}

The documentary analysis of the current development strategies of 22 Ukrainian universities for the period until 2025 found that $59.1 \%$ of them chose the innovative development model. Another $13.6 \%$ envisaged the transition to an entrepreneurial model of activity, $22.7 \%$ operated according to the model of the research university. Two of the research universities (National Technical University of Ukraine "Kyiv Polytechnic Institute named after Igor Sikorsky” and National University "Ostroh Academy") implemented the principles and programmes of academic leadership. Taras Shevchenko National University of Kyiv, Lviv Polytechnic National University and V.N. Karazin Kharkiv National University presented themselves as the basic classical universities, the leaders in the education area of Ukraine.

As the research has shown, the development of conceptual provisions for the strategic development of educational, scientific and innovation activities of universities is usually based on the main principles of modern higher education development, enshrined in Article 6 of the Law of Ukraine "On Education" (Verkhovna Rada of Ukraine, 2017), Article 3 of the Law of Ukraine "On Higher Education” (Verkhovna Rada of Ukraine, 2014). Some universities also define new, additional principles, on which they have to rely in order to achieve certain development strategies of vision and their own mission. Thus, the activities of Sumy State University (Sumy State University, 2019) are also based on the principles as follows:

- democracy, fairness and honesty, which is the basis of a corruption-free university;

- collegiality, collective and individual responsibility, the rule of law in university life, in particular as it is understood at the level of the intra-university regulatory framework of activity;

- compliance with the norms of corporate ethics of the university, mutual respect, tolerance, observance of the right to free expression of one's own opinion;

- priority for ensuring high standards of quality of all aspects of activity;
- systemic motivation for innovative, forward-looking self-development, encouraging creativity, collective and personal leadership;

- organic unity of the research and education process, based on the best modern and future technologies;

- ensuring that all aspects of the university's multifaceted and multidimensional activities are selfsustaining and successful, on an equal footing with priorities, and that they are strategically oriented towards the achievement of common goals;

- the "client-oriented" activities in relation to the requirements and demands of the consumers of university services, the priority of the principle of student-centredness with the formation of an appropriate culture of teacher-student relations at the same time;

- implementation of the philosophy of an "open-type" university for all stakeholders, territorial, professional and other social groups, population, youth; a university open for cooperation, respecting legal norms regarding political neutrality and irrespective of national and religious differences;

- social responsibility for development of the region;

- continuous modernization and internationalization of educational activities, the establishment of close partnerships, primarily with world-class universities, and the study and effective adaptation of the best domestic and international experience.

The basic principles of orientation towards global standards of educational quality and other university values, and alignment with the region's development priorities are also noted in the development strategy (Borys Grinchenko Kyiv University, 2017). As we can see, the formulated principles for improving the activities of universities largely reflect an understanding of the peculiarities of the subsequent stage of their development, the directions of adaptation to the new requirements of the consumers of educational services.

An analysis of the content of educational institutions development strategies has shown that in many cases the developers of strategies have approached them from the perspective of an in-depth analysis of the current state and future development of the educational services market and the university's place in it. In particular, the development strategy of the National Technical University of Ukraine "Kyiv Polytechnic Institute named after Igor Sikorsky" (KPI) (National Technical University of Ukraine "Igor Sikorsky Kyiv Polytechnic Institute”, 2020) notes that in recent years, both the global world and Ukrainian society are passing through a sludge-like stage of development. National interests of the world countries increasingly dominate the benefits of globalization, the fourth industrial revolution is changing the nature and structure of work, new needs and demands of young people for career building through education and vocational training are emerging. The analysis 
of external environment factors has shown that they do not allow the university to linearly transfer the achievements of past years to its future development, and it is concluded that KPI, in the next stage of its evolution, in accordance with the new challenges and requirements of society, has to transform the content and forms of work, placing special emphasis on quality characteristics, to continue integration into the European and world educational and scientific space, introducing standards and criteria of worldclass universities. To this end, the strategy formulates the need to ensure the development of the KPI in such interrelated directions:

- improving the research university model;

- developing the Sikorsky Challenge innovation ecosystem as a model for Ukraine's future high-tech economy;

- fundamentality of training;

- harmony and multi-dimensional nature of educating a new generation of professionals;

- a comprehensive system of pre-university training;

- ensuring interdisciplinarity, consistency and comprehensiveness of training;

- rapid response to changes in the nature and structure of the labour market in the context of the fourth industrial revolution;

- strengthening the direct interaction of the KPI with the high-tech labour market;

- informatization of university management;

- democratization of university life, decentralization of management and widespread introduction of selfgovernance.

Our research, benchmarking methods showed that only a third of the universities studied took a similar fundamental approach to substantiating the direction of their future development. And $36.4 \%$ of universities applied well-known methods for this purpose to analyze their strengths, weaknesses, opportunities and threats to their development (SWOT-analysis).

Taking into consideration its universally recognized brand, the National University "Lviv Polytechnic" (Lviv Polytechnic National University, 2020) provides for the development of its own unique educational environment, the established system of motivating the performance of scientific and scientific-pedagogical staff etc. At the same time, weaknesses of the university are also seen: insufficient development of innovation infrastructure, an imperfect system of student motivation, and so on. The university sees opportunities for its development, for example through increased participation in grant activities (within the Horizon 2020 framework programmes, Erasmus Plus, National Research Foundation, etc.). The university sees threats to its development in the decreasing level of knowledge of university entrants, unstable demand for graduates of certain specialties on the market, increasing competition between domestic HEIs on the educational service market, imperfect mechanisms for the commercialization of human resource developments, and so on.

Virtually all of the strategies of the universities studied provide for measures to ensure development in certain areas. They take into account the peculiarities of each university, their current state, corporate culture and therefore vary in number, detail, manner and depth of substantiation - from the "traditional" set, which usually goes from document to document, to programme measures - ways to implement the strategic objectives of the university.

The research allowed us to conclude that university development strategies are programme documents formed with the consideration of the principles of adapting university activities to the requirements of the environment, its threats, taking into account the opportunities for development in this uncertain environment, and relying on its own preferences. That is, adaptive management is seen as a basic technology for forming strategic documents (strategic plans, projects, and programmes) as a response to current and future threats to the external environment. This vision of the role and place of adaptive management in the strategic management system of HEIs is supported by the elaboration and substantiation of measures to ensure the implementation of the development strategies of the studied universities.

In particular, this can be seen in the ways in which universities are addressing the strategic challenge of improving the education quality of graduates. Thus, the formation of a modern model, a "portrait" of a graduate has become one of the most important components of the ideology of Sumy State University (SumySU). In forming the new ideology of educational activities, the university took into consideration (Sumy State University, 2019) the speed of updating professional knowledge, the rate of information growth, the reorientation of production, the difficulties of finding employment for a "narrow" speciality, and the vision of the specialist model by the personnel. The university has set the task of providing the graduate primarily with the ability to self-study and a foundation on which one can build the necessary professional knowledge and be able to adapt quickly to change. The university recognises that in today's socio-economic conditions, the criteria for effective higher education are not only professional knowledge and skills, but also certain individual and psychological personal qualities that contribute to one's successful socialization and further professional development.

In the substantiation of the tasks to form a new model of the Sumy State University graduate as one of the most important ideologies of the university activities (Sumy State University, 2019) it is declared that the meaningful component of the implementation of this model should take into consideration the evolution and 
rapid changeability of the labour market requirements and social development as a whole. The research component of a graduate's training is intended to develop critical and creative thinking. Regardless of the professional orientation, his or her competencies in energy efficiency philosophy, environmental safety and the like must be ensured. In the substantiation of the competence-based approach to student training, it is noted that the above requires painstaking longterm work, organization of the educational process in accordance with the requirements for the quality of educational services, rethinking the structure of education and ensuring its flexibility, constant updating, modernization of educational programmes and the content of curricula in academic disciplines.

The analysis of existing development strategies of 22 Ukrainian universities also revealed that $86 \%$ of the studied strategies are characterized by the lack of analysis of trends in the development of educational space, peculiarities of the current educational service market and the place and prospects of the institution in it, shallow analysis of strengths and weaknesses, opportunities and threats to the institution, replacing the content of strategic management by a detailed set of measures to ensure its current functioning, and so on. An important reason for this state of affairs is the lack of managers' awareness of the methodology, content and technology of adaptive management of a higher education institution, its adaptation to current and projected changes in the environment of functioning and the lack of sufficient methodological support for these aspects of the institution's management.

\section{Conclusions}

Adaptation of HEIs to the requirements of the external environment is not a one-time action, but a continuous and long-lasting process that in the end should ensure the institution's competitiveness in the regional and national markets of educational services and its high image among the population and entrepreneurs that are consumers of educational services. The scientific and methodological bases of adaptation process support organization in higher education institutions, formulated in the article, take into consideration the specificity of educational activity, the need for its forecasting for the medium and long term, provide for planning of adaptation transformations of HEIs on a long-term basis. In other words, under conditions of dynamic changes in the external environment and the need to take into consideration the prospective nature of specialist training, a systematic, continuous process of adaptation based on forecasts of the external environment development, which is preemptive in nature, should be a necessary principle of the educational institution's activity strategy.

The results of the adaptive management strategy implementation can be determined by the criterion of educational quality improvement, individual educational result of a graduate as a ratio between the actual level of competencies acquired by him or her and the normative, established by the regulatory educational documents competencies for a given educational speciality, specialization. The content of competencies and the methodology for determining their level can be the subject of further scientific research.

\section{References:}

Azrilian, A. N. (ed.) (1999). Bolshoi ekonomicheskii slovar. 4-e izd., pererab. i dop. [The Big Dictionary of Economics. Edited by - 4th ed., Rev. and add]. Moscow: Institut novoi ekonomiki.

Bolgova, M. A., \& Podlegaev, A. B. (2015). Strategii deiatelnosti obrazovatelnykh organizatcii vysshego obrazovaniia v usloviiakh modernizatcii vysshego obrazovaniia v Rossiiskoi Federatcii. Sotcialno-ekonomicheskii analiz [Strategies for the activities of educational institutions of higher education in the context of modernization of higher education in the Russian Federation. Socio-economic analysis]. Bulletin of NMSTU, no. 4, pp. $117-122$.

Borys Grinchenko Kyiv University (2017). Stratehiia (prohrama) rozvytku Kyivskoho universytetu imeni Borysa Hrinchenka na 2018-2022 rr. [The development strategy (programme) of Borys Grinchenko Kyiv University for 2018-2022]. Kyiv: Borys Grinchenko Kyiv University. Available at: https://kubg.edu.ua/prouniversitet/ vizytivka/prohrama-rozvytku.html

Carayannis, E., Barh, T., \& Campbell, D. (2012). The Quintuple Helix innovation model: global warming as a challenge and driver for innovation. Journal of Innovation and Entrepreneurship, 1(2). Available at: https://innovation-entrepreneurship.springeropen.com/articles/10.1186/2192-5372-1-2

Douglas, J. A. (2009). Predprinimatelskaia aktivnost shtatov i issledovatelskie universitety v SShA: politika i novye initciativy na urovne shtatov [The entrepreneurial state and research universities in the United States: Policy and new state-based initiatives]. Voprosy obrazovaniia, no. 1, pp. 60-104.

Foray, D., Goddard, J., Beldarrain, X. G., Landabasso, M., McCann, P., Morgan, K., Nauwelaers, C., \& OrtegaArgiles, R. (2012). Guide to Research and Innovation Strategies for Smart Specialisations (RIS 3), 434 p. Available at: http://ec.europa.eu/regional_policy/sources/docgener/presenta/smart_specialisation/smart_ris3_2012.pdf

Kliachko, T. L. (2002). Strategii adaptatcii vysshikh uchebnykh zavedenii: ekonomicheskii i sotciologicheskii aspekty [Adaptation strategies of higher education institutions: economic and sociological aspects]. Moscow: SI-HSE. (in Russian)

Kuzminov, Ya. I., Semenov, D. S., \& Frumin, I. D. (2013). Struktura vuzovskoi seti: ot sovetskogo k rossiiskomu "master-planu" [Structure of the higher education network: from the Soviet to the Russian "master plan"]. Voprosy obrazovaniia, no. 4, pp. 8-69. 
Lomonosova, O. E. (2020). Teoretychni aspekty adaptatsii zakladiv vyshchoi osvity do zmin zovnishnoho seredovyshcha: sutnist ta osnovni factory [Theoretical aspects of adaptation of higher education institutions to changes in the external environment: essence and main factors]. Scientific and Production Journal "Business Navigator", edition 4(60), pp. 7-12.

Lviv Polytechnic National University (2020). Stratehiia rozvytku "Lvivska politekhnika - 2025" [Development Strategy "Lviv Polytechnic - 2025"]. Lviv: Lviv Polytechnic National University. Available at: https://lpnu.ua/ sites/default/files/2020/pages/2316/strategiya2025.pdf

Makkula, M. (2013). Renewing the Triple Helix in a Context of Smart Specialisation. Available at: https://www.triplehelixassociation.org/helice/volume-3-2014/helice-issue-1/renewing-triple-helix-contextsmart-specialisation

Ministry of Education and Science of Ukraine (2020). Stratehiia rozvytku vyshchoi osvity v Ukraini na 2021-2031 roky: Proekt [Strategy for the Development of Higher Education in Utkraine 2021-2031: Project]. Kyiv: Ministry of Education and Science of Ukraine.

Mochernyi, S. V. (ed.) (2017). Ekonomichna entsyklopediia: u 3 tomakh [Economic Encyclopaedia: in 3 volumes]. Kyiv: Publishing Centre "Akademiia", vol. 1.

National Technical University of Ukraine "Igor Sikorsky Kyiv Polytechnic Institute" (2020). Stratehiia rozvytku Natsionalnoho tekhnichnoho universytetu Ukrainy "Kyivskyi politekhnichnyi instytut imeni Ihoria Sikorskoho" na 2020-2025 roky [Development Strategy of National Technical University of Ukraine "Igor Sikorsky Kyiv Polytechnic Institute" for 2020-2025]. Kyiv: National Technical University of Ukraine "Igor Sikorsky Kyiv Polytechnic Institute". Available at: https://data.kpi.ua/sites/default/files/files/2020-2025-strategy_0.pdf

Saunders, D. (2007). The Impact of Neoliberalism on College Students. Journal of College and Character, vol. 8 , no. 5, pp. 1-9. Available at: https://www.tandfonline.com/doi/abs/10.2202/1940-1639.1620

Sokolova, L.V.(2006). Orhanizatsiino-ekonomichne zabezpechennia adaptatsii pidpryiemstv do nevyznachenosti biznesseredovyshcha: avtoref. dys. na zdobuttia nauk. stupenia dokt. ekon. nauk: spets. 08.06.01 "Ekonomika, orhanizatsiia $i$ upravlinnia pidpryiemstvamy" [Organizational and economic support for enterprises' adaptation to the uncertainty of the business environment: author's abstract for a scientific degree of Doctor of Economics: speciality 08.06.01 "Economics, organization and management of enterprises"]. Donetsk: Institute of Industrial Economics of the National Academy of Sciences of Ukraine.

Sumy State University (2019). Stratehichnyi plan rozvytku Sumskoho derzhavnoho universytetu na 2020-2026 roky [Strategic Development Plan of Sumy State University for 2020-2026], Sumy: Sumy State University. Available at: https://normative.sumdu.edu.ua/?task=getfile\&tmpl=component\&id=52fedeb8-8e42-ea11-b021-001a4be 6d04a\&kind $=1$

Titova, N. L. (2008). Put uspekha i neudach: strategicheskoe razvitie rossiiskikh vuzov [The way of success and failure: strategic development of Russian universities]. Moscow: MAX Press. (in Russian)

Verkhovna Rada of Ukraine (2017). Pro osvitu: Zakon Ukrainy [“On Education”: Law of Ukraine]. Kyiv: Verkhovna Rada of Ukraine. Available at: https://zakon.rada.gov.ua/laws/show/2145-19\#Text

Verkhovna Rada of Ukraine (2014). Pro vyshchu osvitu: Zakon Ukrainy ["On Higher Education”: Law of Ukraine]. Kyiv: Verkhovna Rada of Ukraine. Available at: https://zakon.rada.gov.ua/laws/show/1556-18\#Text

Volkov, A. Ye., Kuzminov, Ya. I., Remorenko, I. M., Rudnik, B. L., Frumin, I. D., \& Yakobson, L. I. (2008). Rossiiskoe obrazovanie - 2020: model obrazovaniia dlia innovatcionnoi ekonomiki [Russian education - 2020: education model for innovation economics]. Voprosy obrazovaniia, no. 1, pp. 32-64.

Zablotskyi, V., Palant, O., Diegtiar, O., Glibko, S., Bielska, T., \& Rusnak, A. (2019). The current state and necessity of transformation of the management system of educational establishments in Ukraine at the local level. Public Policy and Administration, vol. 18, no. 2, pp. 225-240. Available at: https://www3.mruni.eu/ojs/publicpolicy-and-administration/article/view/4945

Zhdamirov, Ye. Yu. (2010). Sutnist adaptatsii upravlinnia funktsionuvanniam pidpryiemstv [The essence of adaptive management of business operations]. Bulletin of Sumy National Agrarian University: Scientific magazine. Series "Economics and Management". Sumy: Sumy NAU, edition 6/1(41), pp. 93-101. 